\title{
Ethnologies
}

\section{Canada Research Chair in Ethnomusicology}

\section{Beverley Diamond}

Volume 29, numéro 1-2, 2007

Retour à l'ethnographie

Back to Ethnography

URI : https://id.erudit.org/iderudit/018755ar

DOI : https://doi.org/10.7202/018755ar

Aller au sommaire du numéro

Éditeur(s)

Association Canadienne d'Ethnologie et de Folklore

ISSN

1481-5974 (imprimé)

1708-0401 (numérique)

Découvrir la revue

Citer cet article

Diamond, B. (2007). Canada Research Chair in Ethnomusicology. Ethnologies, 29(1-2), 317-323. https://doi.org/10.7202/018755ar d'utilisation que vous pouvez consulter en ligne.

https://apropos.erudit.org/fr/usagers/politique-dutilisation/ 


\title{
Canada Research Chair in Ethnomusicology
}

\author{
Beverley Diamond \\ Memorial University, Newfoundland \\ bdiamond@mun.ca
}

Like most Canada Research Chairs, I have been involved with an array of curricular and community initiatives, as well as new research and new reflective / interpretive work. The primary work in each of these areas is described below.

\section{Our Space}

In order to have the studio facilities, meeting space, and resources to undertake a wide array of projects, I established the Research Centre for the Study of Music, Media and Place (MMaP) at Memorial University (www.mun.ca/music/mmap/). The MMaP Centre was officially constituted in January 2003 and, after several years of operating in rather cramped quarters, it has recently moved into new facilities in the Arts and Culture Centre of St. John's. We now have, in addition to office space, a multimedia library, audio restoration facility, multimedia production studio with excellent video as well as audio capability, and a "gallery" space that we use for workshops, media training sessions, small performances, and guest lectures.

The MMaP Research Centre is now viewed within the province as an interface between the university and local communities, a mobilizer of Applied Ethnomusicology projects, and a collaborator in the organization of numerous conferences, concerts and festivals. "Our space," then, operates with a philosophy that differs from "myspace": it is responsible to the community (with community representation on the executive board as well as a committee of regional representatives) and is prepared to serve their interests wherever possible. 


\section{Reaching Out}

A major initiative that ties directly to the research program described below has been to enable better public access to archival resources at Memorial University, particularly the large audio collection of MUNFLA, the Folklore and Language Archive of Memorial University. We initiated production of an archival CD series in 2004. Each CD is packaged in a DVD case to allow sufficient space for extensive print documentation (usually a booklet of approximately 50 pages). Furthermore, each CD has developed a specific theme that represents a shared concern of academics and practitioners: diverse definitions of "tradition" and "modernity," for instance, or the nature of the Newfoundland song canon. Our first two releases, It's Time for Another One: Folk Songs from the South Coast of Newfoundland and Folklore of Newfoundland and Labrador: A Sampler of Songs, Narrations, and Tunes, are distributed nationally by Landwash Distribution (www. landwashdistribution.com). Three more CDs are in various stages of planning or preparation: one is a re-release of a popular local radio program, Saturday Nite Jamboree, packaged with a booklet on the history of early radio in the province; a second is a Canada-wide anthology of traditional fiddling and related instrumental practices, with an emphasis on cultural diversity and little known archival sources; the third will feature archival recordings of Atlantic Canadian Mi'kmaw song. Most of the CDs have had guest producers and several have been collaborations. The fiddle anthology, for instance, is being produced with support from Folkways Alive and the Canadian Museum of Civilization.

In addition to the $\mathrm{CD}$ series, the $\mathrm{MMaP}$ Centre has developed a website with the earliest audio recordings made in Atlantic Canada. MacEdward Leach and the Songs of Atlantic Canada (www.mun.ca/folklore/ leach) was launched in 2004 with over 300 audio clips, community profiles, biographies of artists and considerable historical and contextual material. Both English and Gaelic language material is included. It was expanded and updated for a relaunch in 2006 and will shortly migrate to the Digital Archive Initiative of the Memorial University libraries. The website has served both as a source of information about songs and a key to university holdings that are of interest to Newfoundland and Labrador families. With much appreciated cooperation of MUNFLA, the MMaP Research Centre has made copies of archival recordings for family members who contact us - over four dozen to date. We have 
also funded the digitization of several reference tools, including the "Song Title Index" of MUNFLA and the index of their collection of Canadian vinyl. The database for the latter, with detailed information about musicians, arrangements, recording collaborators, and copyright, is in itself a research tool created in consultation with Neil Rosenberg and myself by Dr. Linda Daniel during three summer work grants acquired by $\mathrm{MMaP}$ in cooperation with MUNFLA. Support for the website has been provided by Industry Canada (Canadian Collections Online) and the AV Preservation Trust.

While many of the "local" initiatives have been audiovisual with print documentation, I have also joined with co-editors Glenn Colton and James Hiller to create a Music issue of Newfoundland and Labrador Studies, currently in press. Other print publications about local initiatives have appeared in Intersections: Canadian Studies in Music and the 2006 Proceedings of the Canadian Society for Traditional Music, forthcoming from Cambridge Scholars Press.

Other projects include our organization and/or collaboration with a number of presenters of performances and conferences. Several oneday symposia have featured a combination of academics and practitioners, as well as local, national and international experts. The first of these, Who Owns Traditional Music? in 2003 was a precursor to a project described below. The second, Women, Music and Technology, built on my long-standing interest in feminist musicology and my affiliation with a Concordia-based research project, "In and Out of the Studio," directed by Dr. Andra McCartney. This symposium also led to a government contract to do research on women and music in Newfoundland and Labrador in the summer of 2005, for which we organized a second one-day symposium involving over fifty women musicians in the province as the initial phase of the research. We hosted an international event in 2005: Post-Colonial Distances: the study of popular music in Canada and Australia with support from SSHRC, the Australian-Canadian Research Council, and in collaboration with the Canadian branch of the International Association for Studies in Popular Music. Papers from this event will be coedited by Denis Crowdy, Daniel Downes and myself and published in an anthology by Cambridge Scholars Press. In 2008, an independent consortium of interested individuals will host the North Atlantic Fiddle Convention, which will come to Canada for the first time. MMaP is playing a supporting role in this initiative which is directed by Dr. Anna Guigné. The culmination 
of a project (described below) on Indigenous Music and Dance as Cultural Property is also being organized by $\mathrm{MMaP}$ in collaboration with the University of Toronto where a meeting of fifty Indigenous artists and ethnomusicologists is scheduled for May 2008.

Other community-oriented initiatives have included the organization of an annual Music, Media and Culture lecture series. Among the distinguished international visitors I have brought to the university have been Kay Kaufman Shelemay (Harvard University), Anthony Seeger (UCLA), Bruno Nettl (University of Illinois), Pirkko Moisala (Abo Akademie, Finland), Jon Fitzgerald (Southern Cross University, Australia), and Deborah Wong (University of California, Riverside). In addition, we have welcomed Canadian scholars and provided opportunities for Memorial University colleagues who often have rare opportunities to present their work to their "home" communities.

\section{Curricular Initiatives}

As CRC in Ethnomusicology, I was happy to play a leadership role in the development of new $\mathrm{MA}$ and $\mathrm{PhD}$ programs in Ethnomusicology at Memorial University. We have attracted high caliber students to this program as evidenced by the fact that eleven of our 2006-2007 cohort of sixteen students have been awarded SSHRC fellowships in support of their research. Kelly Best was our first MA graduate in June 2006, and we anticipate the conferring of two $\mathrm{PhDs}$ within the year to come. We begin to see the fruits of graduate student labour at many conferences and in publications. Their research interests balance attention to local practices and cultural issues with interest in world music. Among their topics are:

- Mi'kmaw music culture in Newfoundland

- Mennonite diasporic music culture in Mexico

- Celticism and the Newfoundland fiddle

- Regional differences in Newfoundland accordion practices

- Inuit music from Arviat: diversity within a community

- Canadian bluegrass organizations and the redefinition of tradition

- Croatian Canadian youth and musical identities

- Choirs and social activism: a Vancouver case study 
- Lyrics of St. John's song writers

- Traditional music performance in two Roman Catholic parishes

- Contemporary Canadian composers and their uses of Aboriginal music styles

- Contemporary Saami popular music in Finland

- Gender issues in the world of Highland piping in Canada

\section{New Research}

While it is easy to list the tangible "deliverables" that have emanated from my position as CRC and my directorship of the MMaP Research Centre, equally important measures (some might argue more important measures) of the CRC program are the advances in knowledge and in the theorization of knowledge that have resulted from new research. The research program that I have undertaken since 2002 as the CRC in Ethnomusicology at Memorial University has involved a number of projects that fall under the broad title of "Traditional Music: Issues of Travel and Translation." These projects include work on music as a means of articulating Aboriginal modernity, on models that get beyond the problematic concept of "identity studies," projects that unpack unspoken ideologies underlying new technologies and their uses, and ethnographic projects relating to intellectual property.

SSHRC-funded research on Indigenous recording artists had begun before my CRC tenure. I was interested in the experience of both Native American and Saami recording artists in the studio and in the global market place more generally. The ways in which the social organization of different occupational spheres was organized was one issue. The hidden ideologies of recording and mixing, with certain preconceived aesthetic ideas (particularly in relation to the sound of the human voice) was another. Ways in which the increasing pressure to contain and define "traditional Indigenous knowledge" were yet another. The struggles over access and ownership were still one more. My research has revealed how traditional practices are layered on to industry conventions. Our case studies also show how local aesthetic preferences and social meanings are negotiated in specific contexts. This work led me to formulate an international project that builds on the earlier research. The "Indigenous Music and Dance as Cultural Property: Global Perspectives" project has begun to mobilize an international dialogue between artistic practitioners, delegates to WIPO and UNESCO, and 
academics about crucial issues of access, usage, and display of traditional song knowledge. With support from SSHRC's Research Development Initiatives program, strategies ranging from protectionism to collective commons initiatives will be compared in online discussion forums and during a conference which I am organizing in May 2008. About half of the project participants are indigenous artists from Native American, Australian Aboriginal, Maori, Saami, Hawaiian, and indigenous Colombian communities. Other participants are ethnomusicologists, folklorists or anthropologists who work on music, dance and related subjects.

A second tangent of my research program looks more closely at the technologies of audition. In a project that will initially be based in Newfoundland and Labrador, we have begun to study the many modes of audio recording that shape and inform our sense of self and our sense of history. Ranging from "field" recordings by folklorists, to private recordings (sometimes inappropriately called "vanity" recordings), to the rise and demise of professional recording studios, this study aims to open the question of what it means to make an audio recording in a number of new directions. The project, "On Record: Audio Recording in Newfoundland and Labrador," has SSHRC Research Grant support from 2006-2009.

Like many recent projects that have criticized the diffuse and overused concept of "identity," my recent work has articulated a paradigm of "alliance studies" as a useful framework for studying the production and reception of music. One important aspect of this approach is the development of a distinction between citation practices and collaboration practices in artistic production and reception. The model has been outlined in an article published in the 2007 journal of the European Seminar for Ethnomusicology.

My program, then, has a number of interrelated dimensions. It is committed to the exploration of issues in music production and reception that are urgent in light of globalizing initiatives and new technological developments. It is devoted equally to the immediate communities of Newfoundland and Labrador, the international indigenous communities with whom I have had close contact for extended periods of time, and the diverse communities who struggle for voice and place in Canada and beyond. The program regards curricular initiatives, applied projects of direct community relevance, 
and more long-term research that has more abstract theoretical aims as complementary, mutually productive at times, and fruitfully divergent at other times.

Beverley Diamond 